\title{
The Development of Local Culture as a Model for the Development of Maritime Tourism: A Study on Ritual Sedekah Laut in Gempolsewu Weleri
}

\author{
Widyatwati, $\mathrm{Ken}^{1}$, Mahfudz ${ }^{2}$ \\ 1. Faculty of Humanities, Diponegoro University, Semarang, Indonesia \\ 2. Faculty of Economics and Business, Diponegoro University, Semarang, Indonesia
}

\begin{abstract}
The Sedekah Laut in Gempolsewu ritual is a traditional ritual of fishermen in Weleri which is held every year. Philosophically, Sedekah Laut is an activity as a form of gratitude to God for the gifts and salvation that has been given. The Weleri Kendal area is included in the Regional Tourism Corridor development plan aimed at developing maritime tourism. This paper focuses on maritime tourism modeling for creative sustainable regional development by developing a unique identity or characteristic in the Weleri area with the aim of increasing community empowerment and income. This article describes the basic concept of developing local culture as a form of maritime tourism development, explaining the relationship between the maritime tourism product model and the development of local culture in the context of empowerment and increasing community income. The basic for the development of local culture includes: Publication or introducing Gempolsewu as a maritime area in Central Java. Developing the diversity of cultural arts of the Gempolsewu community in the form of cultural attractions and making collaborations between cultural attractions and the availability of distinctive culinary delights. Advancing the folk handicraft industry to support the development of maritime tourism areas in Gempolsewu.
\end{abstract}

*Corresponding Author: kenwidyatwati@gmail.com 


\section{Introduction}

Maritime-based tourism is a tourism activity that is supported by various facilities and services available in marine or maritime tourism objects. The Weleri area is included in the Regional Tourism Corridor development plan aimed at developing maritime tourism. Tourism is a temporary movement carried out by humans with the aim of leaving their routine work or residence. Activities are carried out as long as tourists stay in the destination and facilities are made to meet the needs of tourists [1].

An area can be developed as a maritime tourism object if it has the potential to be developed and designed based on tourism components and traditional cultural wealth. Thus, maritime tourism as a tourism product will have more traditional nuances based on local culture.

The potential for marine affairs in Indonesia is very high, making marine tourism a part of the third pillar of the maritime axis [2]. The development of an area to become a maritime tourism place is based on the identification of the supporting elements in the area. The determination of the maritime tourism area must also be balanced with an understanding of the characteristics and socio-cultural structure of the community for economic improvement and development. Tourism planning cannot be separated from community participation and empowerment. Community empowerment emerges in a participatory manner as an alternative to the development approach.

Planning a tourism area is a continuous process and requires the best and most beneficial maintenance of various alternatives to achieve the goal. Tourism area planning involves more roles, participation and community empowerment. Planning for maritime tourism areas focuses more on Community Based Tourism [3].

The development of marine tourism must be able to pay attention to natural resources, community welfare, visitor satisfaction and increase community development unity. The safety factor is one aspect that affects visitor satisfaction. Marine tourism, especially maritime tourism, is the most popular special interest tourism destination in the world [4].

This research focuses on maritime tourism modelling for creative, sustainable regional development by developing a unique identity or characteristic in the Weleri Kendal area. It aims to solve problems related to improving the regional economy.

Based on the description above, the problem in this study is how to develop local cultural potential and community empowerment with a maritime tourism product model for the realization of a maritime tourism area in Kendal Regency.

\section{Methods}

This study uses a qualitative method. The data validity technique in the study was based on Lincoln and Guba's criteria [5]. Namely, the degree of trust, transferability, dependency and certainty. Data analysis using qualitative data analysis. The data obtained in this study were through observation, interviews, and documentation studies $[6,7,8]$. The informant determination technique uses purposive sampling [9].

The interview used was an in-depth interview with an unstructured interview model conducted on ritual heirs, ritual actors, Gempolsewu Village Head, Gempolsewu traditional elders, Gempolsewu community, Tourism Office and cultural and tourism observers. At the time of data collection, documentation was also taken as a complementary instrument in research. The research documents obtained include geographical location, history and development of rituals, ritual functions, planning of 
maritime tourism development programs, including photos, recordings, notes on the facilities and infrastructure to be built.

The data analysis used is direct data analysis, meaning that data recording and processing is carried out from the beginning of data collection and continues until the end of the study concluded.conclusion.

\section{Results and Discussion}

The industrial sector that can be developed and supports the development of a green industry is the tourism sector. The tourism sector is a mainstay of the economy in several countries because it is able to absorb and create jobs for the community [10]. In Indonesia, the tourism sector is ranked fourth as a contributor to the country's foreign exchange, so that the Indonesian government continues to emphasize tourism as a mainstay of national income [11].

The development of maritime tourism areas must be balanced with an understanding of the characteristics and socio-cultural structure of the community. Knowledge of the community's socio-culture is useful in improving the community's economy. It is used to determine the type and level of community empowerment appropriately and effectively [12].

Maritime tourism refers to tourism where the main activities are carried out in the waters, such as sailing, canoeing or diving, while coastal and coastal tourism is part of marine tourism with recreational activities carried out around the coast such as swimming, snorkelling, sunbathing, surfing [13].

Based on the foregoing, the planning and modelling process for maritime tourism areas in Gempolsewu cannot be separated from community participation. Participatory community empowerment is pursued as an alternative to a centralized and bottom-up development approach. The participation process in the framework of empowering the Gempolsewu community is based on two perspectives, namely: a. Community, local involvement in the selection, design, planning and implementation of programs to be implemented. So it can be guaranteed that the perceptions, attitude patterns, mindset and values of public knowledge are taken into account. b. Making feedback to the community is an integral part of tourism area development activities [14].

Guidance in modelling maritime tourism areas must be able to change society from being just a tourism object to being the subject of tourism and development. The maritime tourism area in Gempolsewu can be developed by running the following programs:

\section{a. People's Economic Empowerment}

Efforts to increase community economic empowerment require support through the smoothness and effectiveness of economic empowerment, especially for developing micro. Small cooperative enterprises and microfinance institutions so that people get decent jobs. Therefore, it is necessary to develop economic enterprises and sustainable livelihoods in Gempolsewu.

The people of Gempolsewu have businesses in the batik and culinary fields that utilize seafood, including fish crackers, shrimp crackers, salted fish, shrimp paste, fish jerky. This culinary potential can support Gempolsewu as a maritime tourism area. 
This special culinary is sold not only in certain even, such as during the implementation of the Sedekah Laut ritual, but it has become a new livelihood for the community. The results of this business already have the official trademarks of each craftsman so that the smooth and effective economic empowerment of the Gempolsewu community can be developed in a participatory manner according to community resources.

Rituals and cultural traditions are used by the Weleri community to benefit the concept of culture-based tourism. The community sells souvenirs and souvenirs typical of Weleri with the aim of increasing income and introducing Weleri traditions and culture to tourists. So that tourists who come to Weleri can bring memories in the form of new knowledge about Javanese culture as well as material memories.

\section{b. Socio-Cultural Empowerment}

An integrated approach in managing the social life of the community can be developed through local wisdom and cultural potential. Local governments, as facilitators in identifying activities, mechanisms for solving population problems, improving services, improving the quality of education and improving community services. These elements are taken into consideration in assessing maritime tourism areas. The development of maritime tourism, in general, cannot be separated from the cooperation between local governments and the community so that it has an impact on progress for the community.

The Gempolsewu community has various cultural potentials, including the Sedekah Laut ritual (Sea Alms) or Pramean Tawang, Nyadran ritual, Shadow Puppet (Wayang Kulit), Puppet Show (Wayang Golek), Javanese Drama (Kethoprak). The cultural diversity possessed by the community requires support so that the cultural potential of the community can be widely recognized. The unique cultural potential of the community and originating from maritime wealth can be utilized for the development of Gempolsewu as a maritime tourism area.

Sedekah Laut (pramean Tawang) is an annual event that attracts many tourists to Gempolsewu. The tradition of Sedekah Laut by the people of Gempolsewu is held once a year. Sedekah Laut is a ritual or salvation activity carried out by fishermen in Weleri Kendal which aims to ask for blessings, safety and also as a thanksgiving for the good fortune they get.

The Sedekah Laut procession begins with the recitation of a prayer, bringing the offerings to the sea and then making the offerings into the sea. The offerings are in the form of crops, fishing products, traditional food and buffalo heads. In the implementation of the Sedekah Laut ritual at Weleri, offerings are an essential part that must exist. The offerings that are thrown into the sea are a means of communication for the community with the spirit of the sea guard (danyang or sing mbaureksa). Danyang or sing mbaureksa is spirits who are believed to have the power to protect and provide safety for the Javanese community.

The night before the Sedekah Laut event is held, usually, a joint prayer is carried out by reading the Manaqib by an Islamic religious leader (Kyai), and in the morning, the Sedekah Laut ritual is carried out. After the Sedekah Laut ritual activity is completed, it continues with entertainment. This entertainment 
performance consists of entertainment of a commercial nature and entertainment of the people. Commercial entertainment is entertainment that is commercial in nature intended for the public and tourists who come to Gempolsewu at the time of the Sedekah Laut procession. These rides are provided for the public and tourists for a fee, including boat rides and night markets. Meanwhile, folk entertainment is entertainment aimed at the public and tourists for free, such as Shadow Puppet, puppet show, ketoprak and music performances.

Sedekah Laut ritual or pramean Tawang as a cultural tourism destination is a cultural commodity that can bring value to the Weleri people. As a cultural tourism commodity, the Sedekah Laut ritual or pramean Tawang is the centre for tourism events held by the Kendal Regency Tourism Office. The government and the community act as facilitators in identifying tourism activities

\section{c. Socio-Economic Empowerment}

The The success and implementation of tourism development policies in Gempolsewu are also influenced by social and economic conditions [15]. Social conditions are related to the views, support and community participation in the maritime-based tourism development process in Gempolsewu.

Most of the people of Gempolsewu work as fishermen because the area of Gempolsewu is on the sea coast. The fishing profession is a profession that is passed down from generation to generation. Since ancient times, the people of Gempolsewu have been fishermen; since childhood, they have been taught to go fishing or go to sea.

Places of economic empowerment are associated as distribution channels aimed at reaching target consumers. This distribution system includes location, transportation, warehousing, and packaging [16]

Economic conditions are related to the sources of funds and financial support allocated for maritime-based tourism development in Gempolsewu. Gempolsewu is also known as a place for fish processing, fish skin crackers (krupuk kulit ikan) and shrimp paste (terasi) production. Where the producers have their respective trademarks. The marketing results of this production have reached other areas, including Sukorejo, Limpung and Parakan.

The socio-economic conditions are related to the support of officeholders and elites in the maritime-based tourism development process in Gempolsewu. The socio-economic life of the Gempolsewu community is quite good. In their daily life, they carry out social interactions that lead to pure social contact, such as mutual help and mutual cooperation. The concept of communal harmony is manifested in the implementation of yasinan, tahlil, 35day old baby ritual (selapanan), social gathering, Sedekah Laut rituals and nyadran rituals. 


\section{d. Empowerment of the tourism environment}

Sustainable development in tourism development involves three important things, namely, economy, socio-culture and the environment. The economic dimension is related to increasing economic growth, fighting poverty, changing people's production and consumption patterns in a balanced direction. The socio-cultural dimension relates to efforts to solve population problems, improve community services and improve education. The environmental dimension is an effort to reduce and prevent pollution, waste management and natural resource conservation [17].

The community supports the development of Gempolsewu as a maritime tourism area. The community has a high awareness of preserving and maintaining natural beauty. The people of Gempolsewu currently manage the coastal area around Sendang Si Kucing beach as a marine tourism object, fishing and water sports.

The environment and geographic location of Gempolsewu are very supportive of the development efforts of Gempolsewu as a cultural tourism destination. The management of natural and cultural resources as tourism commodities in Gempolsewu involves the community. This involvement includes the management and utilization of natural resources efficiently and productively.

The efficient and productive management of natural resources in Gempolsewu aims to increase income and welfare for the community in a sustainable manner. This goal is a pillar that jointly and equally supports the existence and preservation of natural and cultural resources for the benefit of the community.

\section{e. Institutional and Human Resources Empowerment}

Empowerment of institutions and human resources in tourist areas emphasizes more on: First; investment in human capital (human capital), namely in the fields of education and health, Second; increasing organizational capacity in rural areas, in addition to village government organizations that jointly have the desire to develop tourism as a sustainable development effort, Third; expand and integrate the mandate of organizations and groups so that efficiency can be achieved, Fourth; improve work culture, hard work, responsibility and frugality, Fifth; eliminate negative, wasteful, consumptive mental and traits that can damage productivity. Meanwhile, education is more directed to increase the abilities and skills of the community in the form of work products needed by the market [18].

The people of Gempolsewu have an open attitude towards advances in technology and information. So that people are enthusiastic about participating in training, handicraft exhibitions and traditional food. Pokdarwis (Tourism awareness group/communities that contribute to tourism management) Gempolsewu often participates in various events and exhibitions on maritime tourism.

The people of Gempolsewu provide services and attractions to tourists to attract tourists to come to Gempolsewu. Tourism elements that can be developed in Gempolsewu include community customs or habits, handicrafts, traditional food, music, art, history of a place, work ethic, traditional beliefs, traditional architecture and traditional clothing.

The community is maximally empowered so that people continue to work and depend on life in their village. So that with the development of the maritime tourism 
area in Gempolsewu, development in Gempolsewu will become faster, reducing urbanization, unemployment and crime.

In developing tourist areas, the impact of an increase in tourists also needs to be minimized, such as environmental damage, cultural and moral degradation of the community, the occurrence of community consumptive patterns, conversion of productive land functions and an increase in crime. This can be overcome with cooperation between officials, office holders and the community.

The most optimal efforts in preventing crime and disaster hazards in general or for maritime tourism are through education and training in managing tourist areas and disaster mitigation from an early age. As for the prevention of maritime tourism hazards in the field, the most effective way is by direct supervision and prevention by the relevant officers [19].

Cooperation in developing tourist areas can have a positive impact on regional development. The community needs to maintain a good impression that has been built. This can be an effective promotional event for tourists who will come to Gempolsewu. In accordance with the principles of maritime tourism development, namely from the community, by the community, and for the community.

\section{f. Maritime Tourism Area Planning}

The planning of a tourist area is a continuous process and requires the best and most beneficial maintenance of various alternatives in an effort to achieve the goal. Planning for tourist areas involves more roles, participation and community empowerment, so the form of planning focuses more on Community Based Tourism. The participatory approach is a strategy in the development paradigm that rests on the community (people-centred development) [20].

The formation of a tourism awareness group (Pokdarwis) is one of the activities carried out in Gempolsewu. The formation of Pokdarwis was carried out by developing the capacity of the community in terms of knowledge, skills and attitude. Based on the foregoing, it is necessary to hold training in English, accounting management, computers and marketing for pokdarwis Gempolsewu. Also, it is necessary to hold regular discussions and evaluations so that no matter how small, the obstacles faced can be quickly overcome. The tourism awareness group (Pokdarwis) has the ability to accommodate the wishes of the community in tourism, in particular the management and utilization of village potentials for the sake of increasing community welfare and prosperity. Thus, the motivation of the community to develop tourism is maintained for the sustainable development of maritime tourism areas in Gempolsewu.

The effectiveness of the Gempolsewu tourism awareness group (Pokdarwis) is a venue for creativity for the community because the formation of Pokdarwis can train, improve and sharpen people's knowledge about tourism. So that the community can develop and manage the tourism potential of their own region as a source of livelihood. A tourism awareness group (Pokdarwis) consisting of community members must have commitment, enthusiasm, willingness, and concern in developing tourism.

The ritual of Sedekah Laut (pramean Tawang) as a commodity in the packaging of cultural tourism provides economic benefits by creating new jobs and shifting livelihoods from farming to trading, parking attendants, tour guides and so 
on. Tourism policies have broad implications, both for tourism activities themselves, as well as for the management of the natural, socio-cultural environment as a resource for increasing income and creating employment opportunities for the community.

Economic and socio-cultural developments in the community are used to reduce the ritual tradition of the Sedekah Laut (pramean Tawang) to become a cultural and traditional tourism destination. So that currently, the Sedekah Laut ritual (pramean Tawang) is becoming better known and recognized by the wider community. The growing social and cultural potential has made the Sedekah Laut ritual (pramean Tawang) a place for the promotion of businesses, products and commodities for public consumption.

The knowledge that develops in the community is a modality in actualizing the rituals of Sedekah Laut (pramean Tawang). Likewise, the development of science and technology can promote the ritual of Sedekah Laut (pramean Tawang) not just a tradition but can increase people's income by making the ritual of Sedekah Laut ( pramean Tawang) a cultural tourism destination.

\section{g. Conclusion}

Gempolsewu has very good tourism potential so that Gempolsewu is adequate as a maritime tourism area. Access to Gempolsewu is easy because the road infrastructure is adequate for 4 -wheeled and 2-wheeled vehicles. The facilities provided by the manager are inadequate, such as clean toilets, souvenir shops, and health clinics for first aid. The marketing strategy applied has not been optimal due to inadequate promotional facilities.

Weak policy standards in achieving the goals of tourism development have resulted in the unavailability of programs and activities for the introduction of tourist objects in the form of maritime-themed festivals and introduction to the outside world in the form of promotions. So that it is necessary to increase the skills of human resources that are directed at maritime tourism. The tourism development policy in Gempolsewu has not yet led to the development of maritime tourism. Even though the vision of tourism development in Gempolsewu leads to the development of maritime tourism, in the field, it still seems the opposite of what was expected.

\section{References}

1. Marpaung, Happy. 2002. Pengetahuan Kepariwisataan. Bandung: ALFABETA

2. Dwi W., H., \& Subekti N., B. Upaya Indonesia Meningkatkan Pariwisata Maritim Melalui Diplomasi Kebudayaan Di Asia Tenggara. Indonesian Perspective, Vol 2 (1): pp. 51-59. (2017)

3. Purbani, D., Yulius, Ramdhan, M., Arifin, T., Salim, H. L., \& Novianti, N. Karakteristik pantai Taman Nasional Wakatobi dalam mendukung potensi wisata bahari : Studi kasus Pulau Wangiwangi Beach characteristics of Wakatobi National Park to support marine eco-tourism : A case study of Wangiwangi Island. DEPIK, Vol 3(2), pp. 137-145 (2014)

4. Rittichainuwat, B. Special Interest Tourism. Newcastle: Cambridge Scholars Publishing. (2018) 
5. Sumaryanto,Totok. Pendekatan Kuantitatif dan Kualitatif dalam Penelitian . Semarang: Unnes (2007)

6. Sugiyono. Metode Penelitian Pendidikan Pendekatan Kuantitatif, Dan Kualitatif Bandung: Alfabeta. (2014)

7. Setyadin. Metode Penelitian Kualitatif: Teori Dan Praktik. Jakarta: Bumi Akasra.(2005)

8. Creswell, J. W. Educational research: Planning, conducting, and evaluating Quantitative and qualitative research.USA:Pearson Education Inc.(2012)

9. Bungin, Burhan. Penelitian Kualitatif: Komunikasi, Ekonomi, Kebijakan Publik dan Ilmu Sosial lainnya.Jakarta: Putra Grafika.(2007)

10. Moenir, H. D. Implementasi Asean Tourism Strategic Plan 2011-2015 Dalam Kebijakan Pariwisata Indonesia Di Masa Pemerintahan Jokowi. Andalas Journal Of International Studies, Vol. 6 (1): pp. 57-78. (2017)

11. Irawan, E. Implementasi Kebijakan Pembangunan Pariwisata Di Kabupaten Banyuwangi. Jurnal Jejaring Administrasi Publik, Vol. 7 (2): pp 757-770. (2015)

12. Oka A. Yoeti. 1997. Perencanaan Dan Pengembangan Pariwisata.. Jakarta: PT. Pradnya Paramitha

13. Tonazzini, D., Fosse, J., Morales, E., Gonzales, A., Klarwein, A., Moukaddem, K., \& Louveau, O. Blue Tourism. Towards A Sustainable Coastal and Maritime Tourism In World Marine Regions. Jurnal Ilmiah Pariwisata, Volume 26 No. 1 Maret 202159 Barcelona: Clme. (2019)

14. Pendit, Nyoman. S. Ilmu Pariwisata. Jakarta: PT Pradnya Paramitha (2002)

15. Shaleh, T. M. Peran Lembaga Adat dalam Pengelolaan Wisata Bahari (Studi Kasus Di Pantai Pandawa Desa Adat Kutuh Badung- Bali). Prosiding Seminar Nasional Tahunan Ke - V Hasil Penelitian Perikanan Dan Kelautan, pp 354-365 (2016)

16. Samosir, Laura Therecia, I Gusti Agung Oka Mahagangga. 2020. Strategi Pemasaran Pantai Dream Island Di Mertasari Desa Intaran Sanur Kauh Kota Denpasar. Jurnal Destinasi Pariwisata p-ISSN: 2338-8811, e-ISSN: 2548-8937 Vol. 8 No 2, pp 189-195 (2020)

17. Budiharsono. Pemberdayaan Lingkungan Desa wisata. Yogyakarta:Lkis. (2006)

18. Nurmanaf,A Rozani. Peningkatan Pendapatan Masyarakat Pedesaan dalam Hubungannya dengan Distribusi Antar Rumah Tangga. Bogor. Litbang Departemen Pertanian. (2012)

19. Taofiqurohman, Ankiq .202 Faktor-Faktor Penyebab Risiko Wisata Bahari Berdasarkan Dinamika Fisik Pantai di Pesisir Selatan Jawa Barat. Jurnal Ilmiah Pariwisata, Volume 26 No. 1 Maret 2021.pp .47-59.

20. Ekajati.1995. Pengembangan Desa Wisata.Yogyakarta: Bentang 